\title{
Factors Influencing the Choice of Savings and Investment Avenues among Teachers
}

\author{
Dr. Joobi V P, Assistant Professor, Sree Narayana Guru College, Chelannur, India. \\ joobisuni@gmail.com
}

\author{
Sri. Vyshak P K, Assistant Professor, Sree Narayana Guru College of Advanced Studies \\ Chelannur, India. vyshakpk13@gmail.com
}

\begin{abstract}
The teachers play a significant role in the society's growth, as they help to shape the mindset of nation as a whole. The attitude of teachers towards consumption, savings and investment would reflect their economic behaviour, which would influence the quality of life and in turn their performance and education system. A wide range of investment avenues with proper investment strategies and financial planning will leads to the teaching community to contribute to economic growth. In this context the study tries to examine the awareness on the different investment avenues and the factors which leads to the choice of savings and investment avenues among teachers. The study makes use of both primary and secondary data. The sample of the study is confined to college teachers and higher secondary teachers in the government and aided sector working in Calicut district. It has been identified from the study that the investment pattern of college and higher secondary school teachers is consistent with the traditional pattern of investment they have been using for years.
\end{abstract}

Keywords - Savings and Investment avenues.

\section{INTRODUCTION}

Teachers are the pillars of the society as the quality of education depends on their knowledge and skills. The important factor which on which the quality lies is their lifestyle and it greatly influenced by consumption pattern, savings and investment (Sivakumar.et.al,2015). Savings \& investments are necessary for unpredictable future in order to meet emergencies in life. Savings means sacrificing the current consumption in order to increase the living standard and fulfilling the daily requirements in future (Harshvardhan, 2013). It means the total accumulated amount of income that is not spent on consumption. In economics, personal savings is defined as personal disposable income minus personal consumption expenditure. Investment is the use of fund with the aim of earning income or capital appreciation. In the investment process, current consumption is sacrificed in order to make a return in the future. The sacrifice that has to be borne is certain but their return in the future may be uncertain. Investment is an activity that is engaged in by the individual who has savings, that is, investment is made from savings or people invest their savings. All investors are savers but all savers are not investors. The extent to which individuals' save is affected by their preference for future over present consumption, their expectation of future income and to some extent, by the rate of interest. Savings plays a vital role in building up household economy as well as national economy (S. Mathivannan.et.al, 2015). Today the teaching community has started realizing the importance of savings and investments. As there is vast scope of savings and investments due to the presence of a large number of small industrialists, businessman and government employees in the city and the circulation of money is also high. In this context the study tries to examine the awareness on the different investment avenues and the factors influencing the savings and investment pattern of teaching community.

\section{REVIEW OF LITERATURE}

Bhardwaj Rajesh, Raheja Rekh and Priyanka (2011), examine - Analysis of Income and Savings Pattern of Government and Private Senior Secondary School Teachers. Mostly government \& private teachers using bank deposits and life insurance to invest their money, in contrast to private teachers, government school teachers got more benefits. The main goal of government teachers ' savings is an emergency and security, while children's education for private teacher.

Dr. Ananthapadhmanabha Achar (2012) studied on -Saving and Investment Behaviour of Teachers - An empirical study. This study defines personal characteristics such as age, gender, marital status, and lifestyle determined the teachers' savings and investment behaviour.And it also concludes that their family characteristics such as monthly revenue, family expenditure, family size and educational 
qualification have appeared as determinants of their savings and investment behaviour

Pandian L and Aranganathan T (2012) conducted a survey in Cuddalore District to evaluate the attitude of salaried people towards savings and investment. The research sample size was 520 participants. The respondents covered various salaried class age groups. It was noted that major savings and investment aspects have been identified as having a secure life and a good future. There is no government Influence for savings habit to be created. Moreover, Investment and savings decisions were also influenced by past wrong investment patterns of the respondent's type of government, public and private investors did not differ

V.R. Palanivelu \& K.Chandrakumar (2013) studied the investment preferences of salaried class in Namakkal Taluk, Tamil Nadu. It shows some variables such as age, educational level, occupation, financial knowledge influences the investment avenue choice decision.

Dr. S. Mathivannan and Dr. M. Selvakumar (2011) in their study entitled saving and investment pattern of school teaches - A study with reference to Sivakasi District, Tamil Nadu mentioned that the teaching community has realized the value of money and money's worth and prepare a budget for the proposed expenses and compare it with the actual expenses they have met so that other tempting and fashionable expenses do not influence them.

Somasundaram (1998) had found out in his study entitled savings and investment patterns of salaried people in Coimbatore district that the most recognized ways of saving among investors were chit funds and bank deposits. At the same time, low-branded methods are UTI schemes and plantation schemes. Moreover, he also concludes that he attitudes of investors were extremely positive and showed their goal of saving for their future needs.

\section{Statement of The Problem}

Teaching community investors represent a crucial section of the Indian financial market and a better understanding of investor preferences, and the behaviour of these investors is essential to the policy formulation on development and controlling of Indian financial system. Teachers function as the basis for developing accountable citizens and human beings. Teachers are well-educated people who understand how to maximize their investment returns. In general, most investors have limited data about financial market trends and various Investment avenues. Sometime it may not be enough to make investment decisions with the data available from the newspaper, media and television and internet. It is very important to know their risk perception and investment objectives of the investors for better decision making. Hence, the present study makes an attempt to understand the savings and investment behaviour of college teachers working in government and aided colleges and higher secondary schools in Calicut district on their different patter of savings and investment. It also makes an attempt to identify the level of awareness and factors influencing the savings and investment pattern of teaching community.

\section{The Reasons for Savings and Investment}

The saving behavior and propensity to investment differ among various type of households. Dividing earned income between consumption and saving and making a high-quality investment is a complex task. Several factors influencing them vary over occupation, consumption level, community. The general purpose behind the savings and investment are

- Emergencies in future: -The funds are necessary in order to meet the consequences in future like sudden accident, repairing of car, house construction, etc.

- Secure future: - After retirement, savings are a source of funds with which the individuals could continue a decent and reasonable lifestyle when all the income streams stops.

- Sudden death: -How can loved ones cope up with the financial problems that may result from the sudden death of any of the family members? Savings helps in coping up with these types of situation.

- Specific purpose or goal / satisfaction: - This might be reason for savings like for e.g.: - for financing the child's education, for the down payment for a car or house or for a holiday.

- Economic development: - Savings play a very important role in building up of the national economy. Through savings, the national income increases that lead to the development of the economy.

- Investment: - Investment is an economic activity of employment of funds with the expectation of receiving a stream of benefits in the future. Investment is mainly done with the objective like wanting a home, creating a regular income after retirement, and possessing money for the child's education

\section{Factors Influencing the Investment Decision}

There are several factors which affect the investment decision. Risk and return are the two ingredients of investment decision. Number of other factors are also there

- Amount of investment: The investible amount may be low in case of an individual investor. There are a number of ways to invest such as bank deposit, mutual fund, LIC, etc. If the investment funds are more, then transferable financial securities such as stocks, debentures may be purchase

- Purpose of investment: The objective of an individual investor may be to save tax, fixed return, appreciation in the value of securities, future demand etc 
- Type of investment: The number of securities available on the market, which one meets the needs of the investor, and the objective should be taken

\section{Investment alternatives}

There are a number of investment avenues
- $\quad$ Timing of purchase: Careful analysis of price changes may help the investor to decide on the proper timing of the purchase and sale of share

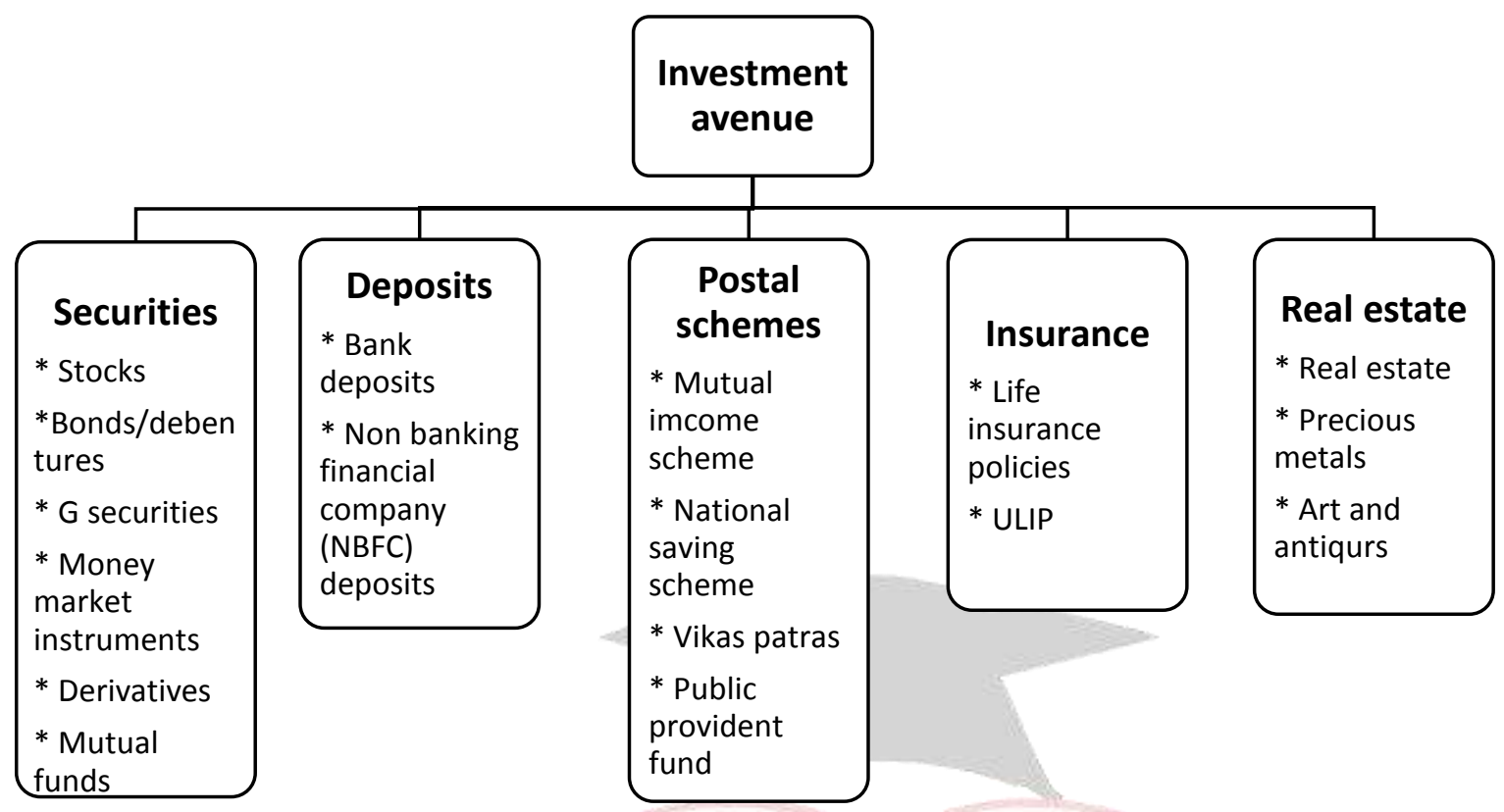

\section{OBJECTIVES}

1. To identity the level of awareness of teachers on various investment avenues

2. To identify the major savings and investment avenues currently used by the teaching community

3. To examine the factors responsible for varying savings and investment patterns across different categories of teachers in the study region.

\section{HYPOTHESES}

- $\mathrm{H}_{0}$ : There is no relationship between income and savings of teachers

- $\mathrm{H}_{0}$ : There is no variation in the level of awareness towards the various investment avenues as to gender of respondents

- $\mathrm{H}_{0}$ : There is no variation in the level of awareness towards the various investment avenues as to age of respondents

- $\mathrm{H}_{0}$ : There is no variation in the responses of the investors of various age, gender regarding factors affecting investment

\section{ReSEARCH Methodology}

Descriptive research design was used to describe the characteristics of the research and respondents involved in the study which is based on both primary and secondary data. Population of the study is the college teachers working in government and aided colleges and higher secondary school in Calicut district. The study is conducted on the basis of the selected sample comprising one hundred twenty (120) with a break-up of 60 College teachers (50 per cent of the total sample) and 60 high secondary school teachers (50 per cent) working in government and aided institutions in Calicut district in Kerala. Convenience sampling method was used for selecting respondents. The primary data was collected with the help of structured questionnaire and secondary data from various available websites, journals and research publications. The variables used for the study includes level of awareness of investment avenues, age, gender, income, savings and factors influencing investment choice etc. The statistical tools and techniques such as tables, percentages, correlation, Mann-Whitney Test, Kruskal-Wallis Test were used for analysing and interpreting the collected data.

\section{DATA ANALYSIS AND INTERPRETATION}

Table 1 Demographic Profile of the Sample 


\begin{tabular}{|c|c|c|c|c|c|}
\hline & \multirow[t]{2}{*}{ Category } & \multicolumn{2}{|c|}{ College teachers } & \multicolumn{2}{|c|}{ HSE teachers } \\
\hline & & Respondents & Percentage & Respondents & Percentage \\
\hline \multirow{5}{*}{ Age } & Less than 30 & 13 & 12.67 & 7 & 11.67 \\
\hline & $31-40$ & 23 & 38.33 & 16 & 26.67 \\
\hline & $41-50$ & 15 & 25 & 27 & 45 \\
\hline & Above 50 & 9 & 15 & 10 & 16.67 \\
\hline & Total & 60 & 100 & 60 & 100 \\
\hline \multirow{3}{*}{ Gender } & Male & 21 & 35 & 19 & 31.67 \\
\hline & Female & 39 & 65 & 41 & 68.33 \\
\hline & Total & 60 & 100 & 60 & 100 \\
\hline \multirow{3}{*}{ Marital status } & Married & 51 & 85 & 52 & 86.66 \\
\hline & Unmarried & 9 & 15 & 8 & 13.33 \\
\hline & Total & 60 & 100 & 60 & 100 \\
\hline \multirow{6}{*}{$\begin{array}{l}\text { Educational } \\
\text { qualification }\end{array}$} & UG with B.Ed & 0 & 0 & 26 & 43.33 \\
\hline & PG with B.Ed & 35 & 58.33 & 34 & 56.67 \\
\hline & PG with M.phil & 5 & 8.33 & 0 & 0 \\
\hline & PG & 12 & 18.33 & 0 & 0 \\
\hline & $\mathrm{PhD}$ & 9 & 15 & 0 & 0 \\
\hline & Total & 60 & 100 & 60 & 100 \\
\hline
\end{tabular}

\section{Source: Primary Data}

\section{Current Investment Avenue}

An investor's savings and investment pattern are formed on the basis of saving behaviour and saving propensity. The financial status of the teachers can be evaluated through their current owned physical and financial assets. The data on investment avenues currently used by teaching community are depicted in Table 2

\section{Table 2 Current Investment Avenue}

\begin{tabular}{|c|c|c|c|c|}
\hline \multirow[t]{2}{*}{ Gender } & \multicolumn{2}{|c|}{ College teachers } & \multicolumn{2}{|c|}{ HSE Teachers } \\
\hline & Yes & No & Yes & No \\
\hline Savings $\mathrm{A} / \mathrm{C}$ & $60(100)$ & $0(0)$ & $60(100)$ & $0(0)$ \\
\hline Fixed deposit & $21(35)$ & $39(65)$ & $15(25)$ & $45(75)$ \\
\hline Gold/Silver & $60(60)$ & $0(0)$ & $52(86.7)$ & $8(13.3)$ \\
\hline Real estate & $14(23.3)$ & $46(76.7)$ & $9(15)$ & $51(85)$ \\
\hline LIC & $46(76.7)$ & $14(23.3)$ & $47(78.3)$ & $13(21.7)$ \\
\hline Post office deposits & $22(36.7)$ & $38(63.3)$ & $23(38.3)$ & $37(61.7)$ \\
\hline Provident fund & $46(76.7)$ & $14(23.3)$ & $49(81.7)$ & $11(18.3)$ \\
\hline Shares/ debentures & $14(23.3)$ & $46(76.7)$ & $6(10)$ & $54(90)$ \\
\hline Mutual funds & $21(35)$ & $39(65)$ & $15(25)$ & $45(75)$ \\
\hline Treasury bills & $0(0)$ & $60(100)$ & $0(0)$ & $60(100)$ \\
\hline Chits \& kurries & $37(61.7)$ & $23(38.3)$ & $33(55)$ & $27(45)$ \\
\hline
\end{tabular}

Source: Primary data 
The table 2 shows that more than 90 per cent of both the group of teachers prefer to invest in savings bank, gold, provident fund and insurance. Only limited number of teachers are invested in innovative financial instruments such as mutual funds, real estate, shares and debentures and none has invested in treasury bills. Some of the individual are more interested in acquiring the financial assets than physical assets.

\section{Level of Awareness on Investment Avenues}

The investment may be of saving bank account, fixed deposit, investment in gold/silver, shares or bonds, treasury bills, mutual fund, real estate, insurance, post office deposits, chitty and kurries. It reveals that how much they are aware of features and benefits of various investments.

Table 4 Level of awareness on various investment avenues

\begin{tabular}{|c|c|c|c|c|}
\hline \multirow{2}{*}{ Investment avenues } & \multicolumn{2}{|c|}{ College teachers } & \multicolumn{3}{c|}{ HSE teachers } \\
\cline { 2 - 5 } & Mean & SD & Mean & SD \\
\hline Savings bank a/c & 4.83 & 0.376 & 4.63 & 0.473 \\
\hline Fixed deposit & 2.97 & 1.365 & 3.23 & 0.909 \\
\hline Gold / silver & 4 & 1.089 & 4.02 & 0.833 \\
\hline Real estate & 2.48 & 1.081 & 2.62 & 0 \\
\hline LIC & 4.38 & 0.904 & 4.17 & 0.806 \\
\hline Post office deposits & 3.45 & 1.141 & 3.78 & 0.993 \\
\hline Provident fund & 4.47 & 0.911 & 3.95 & 0.982 \\
\hline Shares / debentures & 2.67 & 1.160 & 2.62 & 1.106 \\
\hline Mutual funds & 3.32 & 1.372 & 3.13 & 1.065 \\
\hline Treasury bills & 1.58 & 0.979 & 1.68 & \\
\hline Chits and kurries & 4.20 & 1.102 & 4.20 & 0.911 \\
\hline
\end{tabular}

Source: Primary data

The variations of the level of awareness of various investments are described in table 4. From the above table it has been clear that most of the college teachers and HSE teachers are very much aware of savings bank deposit, provident fund and LIC as their mean score is greater than 3 and but they are not much familiar with innovative financial instrument such as treasury bill, shares and debentures as the mean score are less than 3.

\section{Factors Affecting the Investment Choice}

Every investor makes investment by giving importance to various factors. Factors may be risk, liquidity, tax benefits, professional management of the scheme, high returns etc. It reveals that how much they are prioritize the features and benefits of various investments.

Table 5 Factors Affecting the Investment Choice

\begin{tabular}{|c|c|c|c|c|}
\hline \multirow[t]{2}{*}{ Factors } & \multicolumn{2}{|c|}{ College teachers } & \multicolumn{2}{|c|}{ HSE teachers } \\
\hline & Mean & SD & Mean & SD \\
\hline Safety & 4.67 & 0.629 & 4.63 & 0.758 \\
\hline High return & 4.75 & 0.571 & 4.67 & 0.655 \\
\hline Liquidity & 4 & 1.042 & 3.83 & 1.076 \\
\hline Less risk & 4.48 & 0.248 & 4.07 & 0.918 \\
\hline Good customer service & 3.62 & 1.180 & 3.18 & 1.248 \\
\hline Tax benefits & 2.82 & 1.242 & 2.47 & 1.016 \\
\hline Regular return & 3.12 & 1.379 & 3.83 & 1.137 \\
\hline Convenience & 3.43 & 1.254 & 3.37 & 1.529 \\
\hline Cost of investment & 2.85 & 1.205 & 3.50 & 1.097 \\
\hline Availability of income & 3.93 & 0.989 & 3.62 & 1.379 \\
\hline Professional Management & 2.60 & 1.182 & 2.65 & 1.132 \\
\hline
\end{tabular}

Source: Primary data

The Table 5 shows factors affecting investment choice. From the above table it is understood that both the category of teachers is considered the factors such as high return, safety and less risk while selecting investment choice as the mean score of the factors are high. They are considering the factors such as professional management and tax benefits while selecting investment choice. 


\section{Relationship Between Income and Savings}

The relation between income of teachers and their savings with regard sector of job are analysed with correlation analysis and the output is presented in the following table 6.

Ho: There is no significant relationship between income and savings of teachers

Table 6 Relationship between Income and Savings

\begin{tabular}{|l|l|l|l|l|l|}
\hline \multicolumn{1}{|c|}{ Type of job } & \multicolumn{1}{|c|}{ Variables } & \multicolumn{1}{|c|}{ Test applied } & \multicolumn{1}{|c|}{ Type of test } & \multicolumn{1}{c|}{ Test statistic } & \\
\hline College teachers & Income and savings & Pearson Correlation & 2- tailed & .746 \\
\hline HSE teachers & Income and savings & Pearson correlation & 2- tailed & .762 \\
\hline
\end{tabular}

Source: Primary data

In the case of college teachers, the significance level is .00 , which is below $0.01(\mathrm{p}<.01)$ and therefore, there is statistically significant relationship between income of college teachers and their savings. So, we reject the null hypothesis. In case of HSE teachers the significance level is .0000 , which is below $0.01(\mathrm{p}<.01)$ and therefore, there is statistically significant relationship between income of HSE teachers and their savings. So, we reject the null hypothesis

\section{Awareness of Investment Avenue with regard to Gender}

The variations of the level of awareness of various investments with regard to gender wise classification of respondents are analysed with Mann-Whitney Test and hypothesis testing can be stated as follows and the output is presented in the following table 7 .

Ho: There is no significant variation in the level of awareness towards the various investment avenues as to gender of respondents

Table 7 Investment Awareness and Gender

\begin{tabular}{|c|c|c|c|c|c|c|c|c|c|}
\hline Type of job & Gender & $\mathrm{N}$ & $\begin{array}{l}\text { Mean } \\
\text { ranks }\end{array}$ & Variables & Test applied & $\begin{array}{c}\text { Type of } \\
\text { test }\end{array}$ & $\begin{array}{c}\text { Test } \\
\text { statistic }\end{array}$ & $\begin{array}{c}\text { Asymp. } \\
\text { Significanc } \\
\text { e }\end{array}$ & Exact significance \\
\hline \multirow[t]{3}{*}{$\begin{array}{l}\text { College } \\
\text { teachers }\end{array}$} & Male & 22 & 34.11 & \multirow[t]{3}{*}{$\begin{array}{c}\text { Gender and investment } \\
\text { awareness }\end{array}$} & \multirow[t]{3}{*}{$\begin{array}{c}\text { Mann-Whitney U } \\
\text { test }\end{array}$} & \multirow[t]{3}{*}{ 2-tailed } & \multirow[t]{3}{*}{338.5} & \multirow[t]{3}{*}{.219} & \multirow[t]{3}{*}{0.05} \\
\hline & Female & 38 & 28.41 & & & & & & \\
\hline & Total & 60 & & & & & & & \\
\hline \multirow{3}{*}{$\begin{array}{c}\text { HSE } \\
\text { teachers }\end{array}$} & Male & 19 & 33.29 & \multirow{3}{*}{$\begin{array}{c}\text { Gender and investment } \\
\text { awareness }\end{array}$} & \multirow{3}{*}{$\begin{array}{c}\text { Mann-Whitney U } \\
\text { test }\end{array}$} & \multirow{3}{*}{ 2-tailed } & \multirow[t]{3}{*}{336.5} & \multirow[t]{3}{*}{.397} & \multirow[t]{3}{*}{0.05} \\
\hline & Gender & 41 & 29.21 & & & & & & \\
\hline & Total & 60 & & & & & & & \\
\hline
\end{tabular}

Source: Primary data

In the case of college teachers, the significance level is .219 , which is above 0.05 (p>.05) and therefore, there is no statistically significant difference between the level of awareness towards the various investment avenues and gender of respondents. So, we accept the null hypothesis. In case of HSE teachers the significance level is .397, which is above 0.05 ( $p>.05$ ) and therefore, there is statistically no significant difference between the level of awareness towards the various investment avenues and gender of respondents. So, we accept the null hypothesis

\section{Awareness of Investment Avenue with regard to Age}

The variations of the level of awareness of various investments with regard to age wise classification of respondents are analysed with Kruskal-Wallis Test and hypothesis testing can be stated as follows and the output is presented in the following tables 7

Ho: There is no significant variation in the level of awareness towards the various investment avenues as to age of respondents 
Table 8 The Investment Avenue and Age

\begin{tabular}{|c|c|c|c|c|c|c|c|c|c|}
\hline Type of job & Gender & $\mathrm{N}$ & $\begin{array}{l}\text { Mean } \\
\text { ranks }\end{array}$ & Variables & Test applied & $\begin{array}{c}\text { Type of } \\
\text { test }\end{array}$ & $\begin{array}{c}\text { Test } \\
\text { statistic }\end{array}$ & $\begin{array}{c}\text { Asymp. } \\
\text { significance }\end{array}$ & $\begin{array}{c}\text { Exact } \\
\text { significance }\end{array}$ \\
\hline \multirow[t]{5}{*}{$\begin{array}{l}\text { College } \\
\text { teachers }\end{array}$} & Below 30 & 13 & 28.73 & \multirow{5}{*}{$\begin{array}{c}\text { Age and } \\
\text { investment } \\
\text { awareness }\end{array}$} & \multirow[t]{5}{*}{$\begin{array}{c}\text { Kruskal- } \\
\text { Wallis test }\end{array}$} & \multirow[t]{5}{*}{ 2-tailed } & \multirow[t]{5}{*}{6.818} & \multirow[t]{5}{*}{.0018} & \multirow[t]{5}{*}{0.05} \\
\hline & $31-40$ & 23 & 24.46 & & & & & & \\
\hline & $41-50$ & 15 & 35.87 & & & & & & \\
\hline & Above 50 & 9 & 39.56 & & & & & & \\
\hline & Total & 60 & & & & & & & \\
\hline \multirow[t]{5}{*}{$\begin{array}{c}\text { HSE } \\
\text { teachers }\end{array}$} & Below 30 & 7 & 22.36 & \multirow{5}{*}{$\begin{array}{c}\text { Age and } \\
\text { investment } \\
\text { awareness }\end{array}$} & \multirow[t]{5}{*}{$\begin{array}{c}\text { Kruskal- } \\
\text { Wallis test }\end{array}$} & \multirow[t]{5}{*}{ 2-tailed } & \multirow[t]{5}{*}{13.321} & \multirow[t]{5}{*}{.0014} & \multirow[t]{5}{*}{0.05} \\
\hline & $31-40$ & 14 & 23.18 & & & & & & \\
\hline & $41-50$ & 27 & 29.65 & & & & & & \\
\hline & Above 50 & 12 & 45.71 & & & & & & \\
\hline & Total & 60 & & & & & & & \\
\hline
\end{tabular}

Source: Primary data

In case of college teachers, the significance level is .0018 , which is below $0.05(\mathrm{p}<.05)$ and therefore, there is statistically significant difference in the level of awareness towards the various investment avenues as to age of respondents. So, we reject the null hypothesis. In case of HSE teachers the significance level is .0014, which is below 0.05 ( $\mathrm{p}<.05)$ and therefore, there is statistically difference in the level of awareness towards the various investment avenues as to age of respondents. So, we reject the null hypothesis.

\section{Factors Affecting Investment Choice and Gender}

The variations of the factors affecting investments choice with regard to gender wise classification of respondents are analysed with Mann-Whitney Test and hypothesis testing can be stated as follows and the output is presented in the following table 9.

Ho: There is no difference in the responses of the investors of various gender regarding factors affecting investment

Table 9 The Gender and Factors Affecting the Investment

\begin{tabular}{|c|c|c|c|c|c|c|c|c|c|}
\hline Type of job & Gender & $\mathrm{N}$ & $\begin{array}{l}\text { Mean } \\
\text { ranks }\end{array}$ & Variables & $\begin{array}{c}\text { Test } \\
\text { applied }\end{array}$ & $\begin{array}{c}\text { Type of } \\
\text { test }\end{array}$ & $\begin{array}{c}\text { Test } \\
\text { statistic }\end{array}$ & Asymp. Sig. & Exact Sig. \\
\hline \multirow{3}{*}{$\begin{array}{l}\text { College } \\
\text { teachers }\end{array}$} & Male & 22 & 32.32 & \multirow{3}{*}{$\begin{array}{c}\text { Gender and } \\
\text { factors affecting } \\
\text { investment }\end{array}$} & \multirow{3}{*}{$\begin{array}{c}\text { Mann- } \\
\text { Whitney U } \\
\text { test }\end{array}$} & \multirow[t]{3}{*}{ 2-tailed } & \multirow[t]{3}{*}{378.0} & \multirow[t]{3}{*}{.338} & \multirow[t]{3}{*}{0.05} \\
\hline & Female & 38 & 29.45 & & & & & & \\
\hline & Total & 60 & & & & & & & \\
\hline \multirow[t]{3}{*}{$\begin{array}{c}\text { HSE } \\
\text { teachers }\end{array}$} & Male & 19 & 34.66 & \multirow{3}{*}{$\begin{array}{c}\text { Gender and } \\
\text { factors affecting } \\
\text { investment }\end{array}$} & \multirow{3}{*}{$\begin{array}{c}\text { Mann- } \\
\text { Whitney U } \\
\text { test }\end{array}$} & \multirow[t]{3}{*}{ 2-tailed } & \multirow[t]{3}{*}{310.5} & \multirow[t]{3}{*}{.207} & \multirow[t]{3}{*}{0.05} \\
\hline & Gender & 41 & 28.57 & & & & & & \\
\hline & Total & 60 & & & & & & & \\
\hline
\end{tabular}

Source: Primary data

In case of college teachers, the significance level is .338, which is above 0.05 ( $p>.05)$ and therefore, there is no statistically significant difference in the responses of the investors of various gender regarding factors affecting investment. So, we accept the null hypothesis, in case of HSE teachers the significance level is .207 , which is above 0.05 ( $p>.05$ ) and therefore, there is 
statistically no significant difference in the responses of the investors of various gender regarding factors affecting investment. So, we accept the null hypothesis

\section{Factors Affecting Investment Choice and Age}

The variations of the factors affecting investments choice with regard to age wise classification of respondents are analysed with Kruskal-Wallis Test and hypothesis testing can be stated as follows and the output is presented in the following table 10 .

Ho: There is no difference in the responses of the investors of various age group regarding factors affecting investment

Table 10 The Age and Factors Affecting Investment Choice

\begin{tabular}{|c|c|c|c|c|c|c|c|c|c|}
\hline Type of job & Gender & $\mathrm{N}$ & $\begin{array}{l}\text { Mean } \\
\text { ranks }\end{array}$ & Variables & Test applied & $\begin{array}{c}\text { Type of } \\
\text { test }\end{array}$ & $\begin{array}{c}\text { Test } \\
\text { statistic }\end{array}$ & Asymp. Sig. & Exact Sig. \\
\hline \multirow[t]{5}{*}{$\begin{array}{l}\text { College } \\
\text { teachers }\end{array}$} & Below 30 & 13 & 31.12 & \multirow{5}{*}{$\begin{array}{c}\text { Age and } \\
\text { investment } \\
\text { awareness }\end{array}$} & \multirow[t]{5}{*}{$\begin{array}{c}\text { Kruskal- } \\
\text { Wallis test }\end{array}$} & \multirow[t]{5}{*}{ 2-tailed } & \multirow[t]{5}{*}{5.174} & \multirow[t]{5}{*}{.159} & \multirow[t]{5}{*}{0.05} \\
\hline & $31-40$ & 23 & 26.09 & & & & & & \\
\hline & $41-50$ & 15 & 38.73 & & & & & & \\
\hline & Above 50 & 9 & 27.17 & & & & & & \\
\hline & Total & 60 & & & & & & & \\
\hline \multirow{5}{*}{$\begin{array}{c}\text { HSE } \\
\text { teachers }\end{array}$} & Below 30 & 7 & 33.71 & \multirow{5}{*}{$\begin{array}{l}\text { Age and } \\
\text { investment } \\
\text { awareness }\end{array}$} & \multirow{5}{*}{$\begin{array}{c}\text { Kruskal- } \\
\text { Wallis test }\end{array}$} & \multirow{5}{*}{ 2-tailed } & \multirow[t]{5}{*}{5.845} & \multirow[t]{5}{*}{.119} & \multirow[t]{5}{*}{0.05} \\
\hline & $31-40$ & 14 & 37.50 & & & & & & \\
\hline & $41-50$ & 27 & 30.09 & & & & & & \\
\hline & Above 50 & 12 & 21.38 & & & & & & \\
\hline & Total & 60 & & & & & & & \\
\hline
\end{tabular}

Source: Primary data

In the case of college teachers, the significance level is .159 , which is above 0.05 ( $p>.05)$ and therefore, there is statistically no significant difference in the responses of the investors of various age group regarding factors affecting investment. So, we accept the null hypothesis. In case of HSE teachers the significance level is .119, which is above 0.05 ( $>>.05)$ and therefore, there is statistically no significant difference in the responses of the investors of various age group regarding factors affecting investment. So, we accept the null hypothesis

\section{FINDINGS AND SUGGESTIONS}

From the study it has been found that most of the teachers prefer to invest in savings bank, gold, provident fund and insurance. The means score obtained for the level of knowledge of the respondents about stocks, debts, mutual fund, treasury bill is lower. It shows that the knowledge of teachers on various innovative and new generation investment avenues is very low. They should therefore update their awareness of new investments in financial and physical assets and also seek professional assistance before making precious investment choice. It is also clear from the study that most of the respondents are not aware of tax benefits. So investors should consider tax shield benefits relating to the investment opportunities while choosing the investment option that can help in reducing their tax burden.It is also suggested that investment firms should set up special investment schemes to popularize savings and investment among teaching community.A wide range of investment alternatives are accessible in India now. So, the investors themselves, after studying the merits and demerits of the various avenues, choose the best alternatives. College teachers should engage in online trading programs in order to make effective investment choices

\section{CONCLUSION}

Teachers plan for the future and the present by making savings and investment decisions. Risk and liquidity include some differences related to savings and investment choices. The selection of savings and investment options and their anticipated returns and risk are more associated. The investment pattern of college and higher secondary school teachers is consistent with the traditional pattern of investment they have been using for years. Bank deposit is the most preferred investment avenue for almost all respondents. Hundred percent of respondents have savings habit and all of them have bank accounts. Investors are conscious about their safety of investments made. They need safety and reliability for their investments. Teachers 
invest their money in safer environment, need regular income from their investment made with lower risk. The only drawback of the teachers is that they are reluctant to invest in modern investment schemes such as shares, debentures, treasury bills and majority of them are afraid to make risky investment. It has been found that in case of both category of teachers there are no significant difference in the responses of the investors of various age group and gender regarding factors affecting investment. But it is statistically significant difference in the level of awareness towards the various investment avenues as to age of respondents and no significance with regard to gender. Based on the findings, it can be concluded that savings and investment are becoming increasingly essential. Of course, teachers have always been responsible for managing their current investment and have chosen the right investment choice through scientific analysis to earn a stable return.
[9] Somasundaram, An empirical study of Indian individual investor's behaviour, Global Journal of Finance and Management 2(1) (1998), 19-33.

\section{REFERENCES}

[1] Bhardwaj Rajesh, Raheja Rekh and Priyanka (2011), Analysis Of Income And Savings Pattern Of Government And Private Senior Secondary School Teachers, Asia Pacific Journal of Research in Business Management, 2(9), 44-56

[2] Dr. S.Mathivannan and Dr.M. Selvakumar (2011), Saving and Investment Pattern of School Teaches - A study with reference to Sivakasi Taluk, Tamil Nadu, Indian Journal of Finance,5(4).

[3] Dr. Ananthapadhmanabha Achar (2012) —-Saving and Investment Behaviour of Teachers - An empirical study, International Journal of Physical and Social Sciences, 263-286

[4] Harshavardhan N Bhavasar (2013), A study of Savings and Investment Pattern of School Teachers with special reference to Ahmednagar City, Maharashtra. IBMRD's Journal of Management \& Research, 2(1).

[5] Palanivelu V.R., Chandra Kumar K., (2013) A Study on Preferred Investment Avenue among Salaried People with reference to Namakkal Taluk,Tamil Nadu, India, SIES Journal of Management, 7(2), 1-12.

[6] Pandian L and Aranganathan T (2012), Saving and investment attitude of salaried class in Cuddalore district, Journal of Business and Management, 1(1), 4049.

[7] Ramanujam.V and Chitra Devi.K (2012), A Study on Impact of Socio-Economic Profile on Investment Pattern of Salaried and Business People in Coimbatore City, International Journal of Management and Information Technology, 2(1),21-27.

[8] Sivakumar\& N Babitha Thimmaiah. (2015), Savings and Investment Behaviour of School Teachers - a study with reference to Mysore City, Karnataka, International Journal of Management Research \& Business Strategy, 3(4). 